\title{
Evaluating the Effectiveness of the Bird-in-Hand-Dividends Policy in the Stability of Jordanian Listed Banks
}

\author{
Mohammad Sami Ali ${ }^{1}$ \\ ${ }^{1}$ Department of Banking and Finance, Faculty of Economics and Administrative Sciences, Zarqa University, Zarqa, \\ Jodan \\ Correspondence: Mohammad Sami Ali, Department of Banking and Finance, Faculty of Economics and \\ Administrative Sciences, Zarqa University, Zarqa, Jodan. E-mail: Maldahrawi@zu.edu.jo
}

Received: January 30, 2020

Accepted: March 20, 2020

Online Published: June 28, 2020

doi:10.5430/ijfr.v11n4p96

URL: https://doi.org/10.5430/ijfr.v11n4p96

\begin{abstract}
The present paper is empirically scrutinized the long and short-run causalities, which are running from the bird-in-hand dividends policy towards investors' preferences as proxied by banks' stability. Through analyzing a quarterly data set covering the period Q1/1996-Q4/2018; results from the ADF test proved that the series variables became stationary only after including the first difference. However, although the Johansen test showed long-run integrations among variables; findings from the single equation of the error correction model asserted that there are no long-run causalities running from dividends' policy towards investors' preferences as captured by the Z-Score index "ZSI", bankometer model or market capitalization. By contrast, results from the Wald $\chi^{2}$ test proved that except for earnings per share and retained ratio; the solvency of banks is found to be significantly responding to the change in dividends payout ratio. However, since there are short-run correlations among dividends' stability, investors' preferences and banking stability, the study concluded that the ZSI is significantly related to investors' attitudes towards banks' decisions regarding dividends' payments.
\end{abstract}

Keywords: banks' stability, bankometer model, bird-in-hand dividends policy, dividends stability, investors' preferences

\section{Introduction}

The decision of banks to pay or cut dividends is considered as one of the most important issues in the field of corporate finance, as it conducts a vital role to enhance or weaken banks' performance through affecting investors' preferences. Thus, since banks are seen as the most important funds' providers; it sounds to be imperative exploring the implications of dividends' payment in the stability of Jordanian banking system. In this regard, the statistics revealed that the total credit facilities of Jordanian listed banks are JOD 4547 million in 2000, compared with JOD 261112 million by the end of 2018. Additionally, the statistics demonstrated that the stability of Jordanian banks as represented by the ZSI rocketed from 37.5 in 2006 , to 57.16 by the end of 2017 , and similarly the total loans-to-deposit ratio grew negatively by $-12 \%$, during the same period. However, since the statistics of Amman stock exchange exhibited that financial metrics including earnings per share "EPS", dividends payout ratio "DPR", and the retained ratio "RR" fluctuated considerably, the current research attempts to investigate the way of how ASE's investors react to the quarterly change in the EPS, DPR and the RR. This core aim will be accomplished through evaluating the long as well as short run causalities, which are assumed to be run from the bird-in-hand dividends policy towards investors' preferences as proxied by banks' stability, over the period Q1/1996-Q4/2018.

Furthermore, since the stability of banks is highly relied on investors' attitudes regarding dividends; the study is also aimed at assessing the impact of investors' preferences in banks' stability as proxied by the Z-score index. However, due the power of dividends policies to influence banks' stability, researchers in the field of corporate finance initiated plenty studies to assess the impact of dividends policies in the stability of banks and banks' performance. For instance, studies including Agyei (2011) showed significant correlations between the dividends payout ratio along with banks' performance as measured by a firm's value. However, Lilian (2016) debated that variables including dividends per share are insignificantly impacting banks' performance as captured by the ROA. However, through evaluating the effect of dividends' policies in investors' preferences, researchers including Lintner (1956); Gordon and Shapiro (1956) confirmed a significant association between dividends per share and the value of firms. By 
contrast, through relying on the assumptions of the irrelevance dividends theory Miller and Modigliani (1961) argued that the shareholders' wealth or a firm's value are insignificantly related to dividends policy (Almeida, et al., 2015). Although there are several studies concerned with banking stability and investors' behaviour (see e.g. Ali, 2020; Diaconu and Oanea, 2015); however, assessing the effectiveness of the bird-in-hand dividends policy in the stability of Jordanian banking system still to be uncovered yet. Therefore, the current research seeks to cover this gap in literature through evaluating the impact of the bird-in-hand dividends policy in the stability of banks, which are listed at ASE, over the period Q1/1996-Q4/2018. Furthermore, since the proponents of the relevance dividends theory confirmed that investors prefer investing in companies, which are paying dividends instead of focusing on capital gains (see. e.g. Gordon, 1963), the study is also attempted to investigate the ability of investors' preferences to mediate the long and short-run correlations between dividends stability and banks' stability. Consequently, results from this research are expected to update the available literature that is focused on dividends policies and banks' stability, as well as assisting further researchers to find out more information regarding the effectiveness of dividends policies to elaborate investors' preferences. Empirically, the ECM of this research could be followed by further researchers to investigate the impact of dividends policies in the stability of banks as gauged by some other variables or for a different period of time. Beyond that, results from this study will also help investors and banks' managers to realize the role of dividends polices to improve the quality of their investment decisions. Consequently, that will be positively impacting banks' stability, and eventually economic growth and development. However, for a well understanding for the study aims and objectives, the next section discusses the problem statement and the main enquires which are going to be answered in this research.

\subsection{Research Problem and the Key Question(s)}

Due to the significant role of banks in economic growth and development, there are numerous studies concerned with the potential determinants of banks' stability and banks' performance. For instance, the study of Ali (2016) revealed that the liquidity of banks as captured by liquid assets to total assets and total deposits to total assets is significantly affected by the rates of interest and inflation, price to earnings ratio and the market-to-book value ratio, over the long-run. However, Audo (2014) debated that the liquidity of Kenyan banks as captured by liquid assets to liabilities is not related to inflation rates. By contrast, Abdul Karim, et al. (2016); Wahid and Dar (2016) confirmed that banks' stability is statistically impacted by inflation, GDP and interest rates. Inconsistently, Diaconu and Oanea (2015) argued that banks' stability is not influenced by the GDP growth rate. Anyway, since the current research is also focused at measuring the impact of dividends in investors' preferences, the study presents a critical appraisal for the potential determinants of investors' behaviour. In this regard, Haron and Azmi (2006) showed that investors' behaviour is positively impacted by interest rates. However, studies including Ali (2020); Mojgan and Ali (2011) confirmed that investors' behaviour is significantly relating to dividends ratios such as EPS, DYR, and DPS. Consistently, Azam and Kumar (2011) proved that the E/P and the GDP growth rate are significantly affecting the stock index of the Karachi stock market as proxied by investors' behaviour. Studies including Bressan (2017) stated that the non-deposit leverage in the large American banks is positively associated with the dividends payout ratio, while the deposit leverage is found to be negatively correlating with the decisions of banks to pay dividends. Although, the available literature concerned with identifying the determinants of banks' performance and investors' behaviour, however, there is no evidence to support the effect of dividends policies in the stability of Jordanian banking system. Thus, to update the available literature as well as assisting investors to understand the role of dividends' policies in banks' stability, the study aims at evaluating the impact of the bird-in-hand dividends policy in the stability of Jordanian listed banks as proxied by the ZSI, market capitalization, and banks' solvency throughout the period Q1/1996-Q4/2018. Moreover, the core aim of this research will be mainly accomplished through answering the following main questions:

1. Does the stability of banks relate to the quarterly change in the bird-in-hand dividends policy during the long-run?

2. Can the bird-in-hand dividends policy be used as a signal to elaborate the stability of banks, during the short-run?

3. Does the relationship of dividends stability along with investors' preferences affect the stability of Jordanian banking system?

4. Are Amman stock exchange's investors following the relevance or irrelevance dividends theory?

\section{Empirical Review}

\subsection{Dividends Policies and Banks' Performance}

In an attempt to evaluate the way of how banks' stability responds to the quarterly update in dividends' decisions, the 
study discussed the irrelevance and relevance dividends policies as well as the impact of dividends policies in banks' performance. However, though the former dividends policy assumes that a firm's value is not related to dividends' polices, the later argues that a firm's dividends policy is significantly impacting a firm's value and stock prices. In other words, the bird-in-hand policy believes that the change in dividends is significantly affecting a firm's value through impacting stock prices. This view was initially supported by Lintner (1962) and Gordon (1963) as they detected a significant correlation between dividends and a firm's value. Similarly, since investors of this theory prefer dividends over capital gains, which are to some extent seen to be uncertain; authors including (Lundgren, 2016) asserted that a firm's value is significantly related to dividends' policies. Nevertheless, the irrelevance dividends policy argues that investors do not rely on dividends, while making their investment decisions. In this context, authors including Miller and Modigliani (1961) debated that investors behave rationally, especially in perfect stock markets, since all information is available for them and can be accessed equally without costs. However, through evaluating the effect of dividends policy in the performance of Kenyan listed banks, Lilian (2016) showed that banks' performance as proxied by ROA is insignificantly related to dividends per share. By contrast, Agyei (2011) argued that the performance of Ghanaian banks as captured by banks' value is significantly influenced by the dividends payout ratio during the period 1999-2003. Likewise, through investigating the effect of dividends policies in the market value of Kenyan banks, (Luvembe, et al., 2014) showed that the value of banks is positively relating to both dividends payout ratio and corporate earnings, over the period 2006-2010. Consistently, Amidu (2007) revealed that banks' return on assets is positively related to dividends policy and growth in sales, while variables like dividends payout ratio and leverage ratio are found to be negatively impacting the return on assets ratio. Paradoxically, Jepkemoi, et al. (2019) argued that the dividends payout ratio is insignificantly related to the financial performance of Kenyan commercial banks, as captured by banks' capital structure and liquidity. Furthermore, in an attempt to ascertain the influential variables of dividends payout's decisions (Imran, et al., 2013), proved that the decisions of dividends payout as captured by the current year dividends are statistically impacted by earnings per share, previous dividends payouts, capital ratio and bank's size. Additionally, the study showed that dividends payouts of the listed Pakistani banks are negatively responding to banks' cash flow.

\subsection{Banking Stability Critical Appraisal}

The review of previous studies showed that there are many researchers concerned with exploring the influential variables of banks' performance and banks' stability. In this regard, researchers including Diaconu and Oanea (2015) argued that the stability of Romanian banking system as measured by the ZSI is not associated with the GDP rate, while it is conversely responding to the change in loans/ deposit ratio. However, the study delivered that the profitability of banks as captured by ROA is significantly impacted by GDP growth rate. Nevertheless, according to Wahid and Dar (2016), the stability of Islamic and commercial banks is statistically affected by bank's size, equity/total assets and income diversification. However, the study revealed that banks' stability as gauged by the ZSI is negatively linked with inflation. However, through classifying Malaysian banks into three main categories, namely, commercial banks, Islamic banks and overall banking industry, (Abdul Karim, et al., 2016), revealed that the stability of commercial and overall banking industry models as represented by the ZSI is significantly related to interest, inflation and the GDP growth rates, during the long-run. Anyway, through slighting the light for identifying the influential factors of banks' liquidity and banking performance (Audo, 2014) showed that the liquidity of Kenyan commercial banks, as captured by liquid assets to liabilities is not affected by the rate of inflation. By contrast, Ali (2016) debated that the liquidity of Jordanian commercial banks as captured by liquid assets/total assets and total deposits/total assets is significantly co-integrated with interest and inflation rates, price/earnings ratio and market/book value ratio, over the long-run. Nevertheless, the liquidity of banks as proxied by liquid assets/total deposits and total loans to total deposits is found to be insignificantly correlated with market fundamentals. By contrast, Fadare (2011) debated that banks' liquidity as gauged by total loans/total deposits is significantly impacted by the monetary policy interest rate and the lagged loans to total deposit ratio. Additionally, studies like Subedi and Neupane (2013) asserted that the liquidity of Nepalese banks as captured by liquid assets/total assets and ROA is negatively related to inflation rate, short-term interest rate, GDP growth rate and the capital adequacy ratio. Consistently, Riaz and Mehar (2013) confirmed that the profitability of Romanian banks as captured by ROA is significantly associated with interest rates, while insignificantly related to total deposits/total assets and banks' credit risk. In the same vein, Irungu (2013) affirmed that the performance of Kenyan banks as measured by ROA is positively impacted by interest rate, liquid assets/total assets, GDP growth rate and the saving deposits' ratio. Beyond that, studies including Haron and Azmi (2006) showed that the GDP growth, inflation and interest rates are significantly impacting the performance of Malaysian commercial banks as measured by banks' deposits. However, through measuring the impact of macroprudential policies, banks' characteristics and banks' ownership in banks' stability as captured by the Z-score index; (Oktaviyanti and Purnawan, 
2019) found that the stability of banks is significantly impacted by variables such as the requirement reserve and the GDP growth rate.

\subsection{Hypotheses' Development}

This paper is empirically assessed the effectiveness of bird-in-hand dividends policy in banks' stability as captured by the ZSI, MC and the bankometer model. Thus, in an attempt to accomplish the core aim of this research, the study focuses on testing the following main hypotheses:

- The review of previous related studies revealed that the way of how companies decide to distribute dividends exerts a vital role in affecting a firm's value and investors' behaviour. Thus, due to the importance of dividends in the process of decision making, there are many researches concerned with testing the impact of dividends in banks' performance and investors' behaviour. For instance, in an attempt to examine the correlation between dividends payout ratio and banks' performance Agyei (2011) confirmed that banks' performance is significantly related to the payout ratio. Additionally, Lintner (1956); Gordon and Shapiro (1956) revealed that the value of firm is significantly affected by dividends per share ratio. Accordingly, the researchers argued that investors prefer to acquire a company's share through focusing on dividends instead of looking for capital gains. Further dividends' theories debated that shareholders' wealth or a firm's value is insignificantly related to dividends policies (Miller and Modigliani, 1961). Thus, through relying on the above discussion, the present research formulated the set of the following null hypotheses:

$\mathbf{H}_{\mathbf{0 1}}$ : The stability of Jordanian listed banks is insignificantly related to the bird-in-hand dividends policy.

This main hypothesis is divided into the following sub-hypotheses:

$\mathbf{H}_{01.1}$ : The stability of Jordanian listed banks is insignificantly related to the bird-in-hand dividends policy during the long-run.

$\mathbf{H}_{\mathbf{0 1 . 2}}$ : The stability of Jordanian listed banks is insignificantly related to the bird-in-hand dividends policy during the short-run.

- The critical appraisal of previous researches revealed that there are several studies concerned with exploring the impact of dividends' policies on investors' attitudes. For example, a study by Ali (2020) hypothesized that the behaviour of Amman stock exchange's investors is significantly related to the volatility in the EPS and dividends payout ratio during the long and short-terms. As a result, the study showed significant correlations of investors' perceptions along with dividends' policies during the long-run. Previously, the researcher delivered that banks' liquidity as a proxy for investors' behaviour is significantly related to the change in the price to earnings ratio (Ali, 2016). Additionally, studies including Abdul Karim, et al. (2016) revealed that banks' stability as captured by the ZSI is significantly related to the interest, inflation and GDP growth rates, during the long-run. However, Mojgan and Ali (2011) confirmed that investors' behaviour is significantly related to EPS and DPS. Consistently, Azam and Kumar (2011) proved that the E/P and the GDP growth rate are significantly affecting the stock index of Karachi stock market as proxied by investors' behaviour. Although, the available literature slighted the light for identifying the determinants of banks' performance and investors' behaviour, however, there is no evidence to support the effect of dividends policies in the stability of Jordanian banking system, or the validity of investors' perceptions to mediate the relationship of dividends policies along with banks' stability. Therefore, the following hypothesis is also going to be tested:

$\mathbf{H}_{\mathbf{0 2}}$ : Investors' preferences are not significant to mediate the long or short-run causalities, which are running from dividends' stability towards the stability of banks as captured by the ZSI.

\section{Research Methodology}

This research evaluated the effectiveness of the bird-in-hand dividends policy in the stability of Jordanian listed banks as captured by the ZSI, BM and MC. For this purpose the study intended to analyze a time series data relates to all Jordanian listed banks, which are 15 in total, during the period Q1/1995-Q4/2018. However, due to data inconsistency the study restricted to deal with a quarterly data set covered the period Q1/1996-Q4/2018, as well as the Safwa Islamic bank was excluded from the sample of this research. However, since the present research is mainly focused on testing hypotheses, those are primarily built through relying on the available literature, the positivism paradigm was adopted to achieve the core aim and objectives of this research. Therefore, the study used a set of empirical measurements like the ADF, Johansen Co-integration, ECM and the Granger Causality Wald tests in order to analyze a quarterly data set covering the period Q1/1996-Q4/2018. The used data are majorly drawn from the financial statements as well as financial reports, which are published by the statistical bulletins of ASE, the official sites of 
Jordanian central bank and the site of global economy (ASE, 2020; CBJ, 2020; the Global Economy, 2020). Moreover, since the study relies on time series variables, after running the descriptive test; the study applied the Augmented Dickey Fuller test to check for data stationarity. Thus, since the variables are found to be integrated of the same order $\mathrm{I}(\mathrm{I})$, the study restricted to run the Johansen co-integration test. Thereafter, the ECM and the Wald tests were applied to find-out whether banks' stability is being granger caused by the bird-in-hand dividends policy during both the long and short-terms.

\subsection{Variables Measurements}

For the purpose of accomplishing the core aim of this research, the study employed a set of quantitative-continuous explanatory and dependent variables. These variables and their measurements are described as shown in Table 1.

Table 1

\begin{tabular}{|c|c|}
\hline Independent Variables & Measurement \\
\hline Dividends Payout Ratio $=\frac{\mu D P S^{t}}{\mu E P S^{t}}$ & $\begin{array}{l}\text { Where, DPS represents the average of banks" } \\
\text { dividends per share, divided by earnings per share, } \\
\text { during the time " } \mathrm{t} \text { " } \mathrm{Q} 1 / 1996-\mathrm{Q} 4 / 2018 \text {. }\end{array}$ \\
\hline Earnings per Share $=\frac{\mu B N P^{t}}{\mu N B O S^{t}}$ & $\begin{array}{l}\text { Where, the BNP relates to the average of banks' net } \\
\text { profit, divided by the average of banks' outstanding } \\
\text { shares, during the time " } \mathrm{t} \text {. }\end{array}$ \\
\hline Retained Ratio $=\frac{\mu N e t \text { Profit }-\mu \text { Dividends Amounts }}{\mu \text { Net Profit }}$ & $\begin{array}{l}\text { It relates to the average of banks' net profit minus } \\
\text { the average of distributed profits, related to the net } \\
\text { profit's average. }\end{array}$ \\
\hline Dividends Stability_Dummy & $\begin{array}{l}\text { It relates to banks' decisions regarding dividends, } \\
\text { and it took } 1 \text { when the relationship of EPS along } \\
\text { with DPS is found to be positive, while - } 1 \text { when it is } \\
\text { found to be negative. DS_DUM =+1 or }-1 \\
\text { ylelds } \\
\longrightarrow E P S \% \leftrightarrow D P S \%\end{array}$ \\
\hline Dependent Variables & Measurement \\
\hline $\mathrm{BS}=\frac{\sum 1.5 X C A+1.2 X T E T A+3.5 X C A R+0.6 X N P L+0.3 X C I+0.4 X T L T A}{T N L B_{t}}$ & $\begin{array}{l}\text { Where, BS represents banks' solvency, CA is the } \\
\text { summation of banks' capital ratio, TETA stands for } \\
\text { total equity/ assets ratio, CAR is the capital adequacy } \\
\text { ratio, NPL refers to non-performing loans, CI is the } \\
\text { cost of income ratio, and the TLTA represents the } \\
\text { total loans/total assets ratio and TNLB relates to the } \\
\text { total number of listed banks during the time t. }\end{array}$ \\
\hline Z-Score Index $=\frac{\left(\frac{\sum \text { ROA }+\left(\frac{\sum \text { EQUITY }}{\sum \text { ASSETS }}\right)}{\sum \sigma \cdot R O A}\right)}{T N L B_{t}}$ & $\begin{array}{l}\text { Where, the } \sum \text { ROA represents banks' return on assets } \\
\text { ratio, the } \sum \text { Equity relates to banks' equity, the } \\
\sum \text { Assets refers to banks' total assets, and the } \sigma . \text { ROA } \\
\text { stands for the standard deviation of return on assets } \\
\text { ratio. }\end{array}$ \\
\hline Banks'Market Capitalization $=\mu S C L X \mu N B O S$ & $\begin{array}{l}\text { Where, the } \mu \mathrm{SCL} \text { represents the average of stock } \\
\text { closing prices multiplied by the average number of } \\
\text { banks' outstanding shares. }\end{array}$ \\
\hline
\end{tabular}

Investors' Preferences_Mediator: Relates to investors' willingness to acquire the stock or entering the stock market.

This variable was captured by the growth of banks' stock prices $=\frac{\boldsymbol{S C P _ { t } -} \boldsymbol{S C P _ { t - 1 }}}{\boldsymbol{S C P _ { t - 1 }}}$. Thus, since the increase in stock demand is assumed to increase a stock price, the study aims at checking whether dividends stability affects the stability of banks, via affecting investors' willingness to acquire the stock.

\section{Estimation Procedures}

Since results from Johansen test confirmed that the variables are integrated over the long-run, the following single 
equation of the VECM was applied, instead of using the simple multiple regression model:

$$
\begin{aligned}
\Delta J L B S_{i t}= & \beta_{0} \pm \sum_{i=1}^{k-1} \beta_{1 i} \Delta J L B S_{t-i} \pm \sum_{i=1}^{k-1} \beta_{2 i} \Delta \sigma . E P S_{t-i} \pm \sum_{i=1}^{k-1} \beta_{3 i} \Delta \sigma . D P R_{t-i} \pm \sum_{i=1}^{k-1} \beta_{4 i} \Delta \sigma . R R_{t-1} \\
& \pm \sum_{i=1}^{k-1} \gamma_{1} \sigma . E P S_{t-i} \pm \sum_{i=1}^{k-1} \gamma_{2} \sigma . D P R_{t-i} \pm \sum_{i=1}^{k-1} \gamma_{3} \sigma . R R_{t-i} \pm \psi_{i} \varepsilon_{t-1} \pm \mu_{t}
\end{aligned}
$$

Where, $\triangle J L B S_{i t}$ is the difference operator of Jordanian listed banks' stability as captured by the ZSI, BM and MC and it is used as a main proxy for investors' preferences. $\beta_{\mathrm{i}}$ : $\mathrm{i}=1 \ldots 4$ relate to the short-run dynamics, and they are the parameters to be estimated. While the $\gamma \mathrm{i}$, parameters relate to the long-run multipliers. $\Psi_{\mathrm{i}} \varepsilon_{t-1}$ is the first lagged period of the error correction term, and $\mu_{\mathrm{t}}$ refers to the white noise error term with usual properties. However, to check the likelihood of utilizing investors' preferences as a mediator that to mediate the relationship between dividends' stability and the ZSI; the following models are going to be tested:

$$
\begin{aligned}
& \Delta \sigma . Z S I_{i t}=\beta_{0} \pm \sum_{i=1}^{k-1} \beta_{1 i} \Delta Z S I_{t-i} \pm \sum_{i=1}^{k-1} \beta_{2 i} \Delta \text { Dividends'Stability }_{\text {Dummy }} \\
& \pm \sum_{i=1}^{k-1} \gamma_{1} \text { Dividends'Stability }_{\text {Dummy }_{t-i}} \pm \psi_{i} \varepsilon_{t-1} \pm \mu_{t} \\
& \Delta \sigma . I P s_{i t}=\beta_{0} \pm \sum_{i=1}^{k-1} \beta_{1 i} \Delta \sigma . I P s_{t-i} \pm \sum_{i=1}^{k-1} \beta_{2 i} \Delta \text { Dividends'Stability }_{\text {Dummy }} \\
& \pm \sum_{i=1}^{k-1} \gamma_{1} \text { Dividends'Stability }_{\text {Dummy }_{t-i}} \pm \psi_{i} \varepsilon_{t-1} \pm \mu_{t} \\
& \Delta \sigma . Z \text { SI }_{i t}=\beta_{0} \pm \sum_{i=1}^{k-1} \beta_{1 i} \Delta \sigma . Z S I_{t-i} \pm \sum_{i=1}^{k-1} \beta_{2 i} \Delta \text { Dividends'Stability }_{\text {Dummy }} \pm \sum_{t-i}^{k-1} \beta_{3 i} \Delta \sigma . \text { IPs }_{t-i} \\
& \pm \sum_{i=1}^{k-1} \gamma_{1} \text { Dividends'Stability_Dummy }_{t-i} \pm \sum_{i=1}^{k-1} \gamma_{2} \sigma . I P s_{t-i} \pm \psi_{i} \varepsilon_{t-1} \pm \mu_{t}
\end{aligned}
$$

Where, the IPs refers to investors' preferences and it is employed as a mediator. Thus, after confirming that there is a significant correlation between dividends' stability and ZSI, as well as dividends' stability along with IPs, model number (4) is going to be considered to check whether IPs is valid to adjust the relationship of dividends' stability along with banks' stability as captured by the ZSI.

\section{The Study Findings and Discussion}

In an attempt to assess the effectiveness of the bird-in-hand in the stability of Jordanian listed banks, the current research employed a set of advanced empirical techniques like the descriptive test, ADF, Johansen, ECM and the granger causality Wald tests, in order to analyze a quarterly time series data covering the period Q1/1996-Q4/2018. Consequently, results from these tests are demonstrated as shown in tables 2-12:

This table presents results from descriptive test, which is conducted to explain the variables' data in terms of means, standard deviations, variances, skewness and kurtosis.

Table 2. Descriptive test

\begin{tabular}{lllllll}
\hline Variable & \# Of Obs. & Mean & Std. & Variance & Skewness & Kurtosis \\
\hline Stock Price\% & 92 & 0.0641 & 0.3017 & 0.09103 & 1.304 & 3.352 \\
\hline Z-Score Index & 92 & 42.933 & 12.916 & 166.82 & -0.22 & 1.421 \\
\hline EPS & 92 & 0.0014 & 0.0013 & 1.7200 & 2.975 & 12.77 \\
\hline DPR & 92 & 0.0004 & 0.0001 & 3.1900 & 0.800 & 4.604 \\
\hline RR & 92 & 0.0040 & 0.0176 & 0.0003 & 4.470 & 21.00 \\
\hline Dividends Stability & 92 & 0.2173 & 0.9980 & 0.9960 & -0.44 & 1.198 \\
\hline Bankometer & 92 & 0.8083 & 0.9451 & 0.8933 & 1.623 & 5.003 \\
\hline MC & 92 & 10.040 & 0.3481 & 0.1211 & -0.417 & 1.424 \\
\hline
\end{tabular}


The above Table 2 reports that throughout the study's period the used variables are found to exhibit significant variations in terms of magnitude. However, except for EPS, DPR and RR the standard deviations of other variables are found to be relatively high. In addition, variables including the growth in stock prices, EPS, DPR, RR and banks' solvency are found to be highly skewed to the right. On the other hand, since kurtosis's values of the ZSI, MC and dividends' stability are found to be less than 3 the variables' data seemed to have flatness, and they are lighter-than-normal tails. By contrast, variables including stock's growth, EPS, DPR, RR and banks' solvency are found to be sharply peaked and having heavier-than-normal tails.

The following table presents results from ADF, which is used to check for data stationarity.

Table 3. Augmented dickey fuller test

\begin{tabular}{llllllll}
\hline Variable & At level 5\% & \multicolumn{7}{c}{$\mathbf{1}^{\text {st }}$ Diff } & & \\
\cline { 2 - 8 } & \# Of Lags & P-Value & T-Stat & $\mathbf{5 \%}$ & P-Value & Remark & $\mathbf{H}_{\mathbf{0}}$ \\
\hline EPS & 5 & 0.31 & $-4.65^{* * *}$ & -3.60 & 0.00 & $\mathrm{I}(\mathrm{I})$ & Rejected \\
\hline DPR & 5 & 0.31 & -3.80 & -3.60 & 0.01 & $\mathrm{I}(\mathrm{I})$ & Rejected \\
\hline RR & 5 & 0.19 & -4.93 & -3.60 & 0.00 & $\mathrm{I}(\mathrm{I})$ & Rejected \\
\hline Bankometer & 5 & 0.15 & -4.01 & -3.60 & 0.00 & $\mathrm{I}(\mathrm{I})$ & Rejected \\
\hline ZSI & 5 & 0.78 & -4.28 & -3.60 & 0.00 & $\mathrm{I}(\mathrm{I})$ & Rejected \\
\hline MC & 5 & 0.68 & -3.69 & -3.60 & 0.02 & $\mathrm{I}(\mathrm{I})$ & Rejected \\
\hline Stock Price\% & 5 & 0.50 & -4.09 & -3.60 & 0.00 & $\mathrm{I}(\mathrm{I})$ & Rejected \\
\hline Dividends Stability & 5 & 0.52 & -3.93 & -3.60 & 0.01 & $\mathrm{I}(\mathrm{I})$ & Rejected \\
\hline Not
\end{tabular}

Note: *** indicates that the time series variables are significant at $5 \%$ level of significance.

Results from Table 3 confirmed that when the used series variables tested at levels, they are found to be non-stationary. However, in order to avoid the problem of getting spurious results the variables are converted into the first difference. Thus, after including the first difference the variables became stationary, as well as integrated of the same order I(I).

This table describes results from Johansen test, which is conducted to check the long-run integration among dividends' polices and banks' stability.

Table 4. Johansen co-integration results

\begin{tabular}{|c|c|c|c|c|c|c|}
\hline \multicolumn{7}{|c|}{$\begin{array}{l}\text { VEC-rank Banking Stability, EPS, DP } \\
\text { Johansen Co-integration Test }\end{array}$} \\
\hline \multicolumn{5}{|c|}{ Trend: Constant } & \multicolumn{2}{|r|}{$\#$ Obs. $=90$} \\
\hline \multicolumn{5}{|c|}{ Sample: Q3/1996/Q4/2018 } & \multicolumn{2}{|r|}{ Lags $=2$} \\
\hline \multicolumn{7}{|c|}{ Maximum } \\
\hline \multirow[b]{2}{*}{ Rank } & \multirow[b]{2}{*}{ Parms } & \multirow[b]{2}{*}{$\mathrm{H}_{0}$} & ZSI & $\mathrm{BM}$ & $\mathrm{MC}$ & \multirow{2}{*}{$\begin{array}{l}\text { Banking Stability, EPS, DPR, RR } \\
1 \% \text { Critical }\end{array}$} \\
\hline & & & $\begin{array}{l}\text { Trace } \\
\text { Statistic }\end{array}$ & $\begin{array}{l}\text { Trace } \\
\text { Statistic }\end{array}$ & $\begin{array}{l}\text { Trace } \\
\text { Statistic }\end{array}$ & \\
\hline $\mathbf{0}$ & 24 & $\mathrm{R}=0$ & 76.73 & 84.45 & 66.07 & 61.21 \\
\hline 1 & 31 & $\mathrm{R} \leq 1$ & 44.06 & $39.67 *$ & 42.09 & 40.49 \\
\hline 2 & 36 & $\mathrm{R} \leq 2$ & $20.03 *$ & 14.14 & 20.72 & 23.46 \\
\hline 3 & 39 & $\mathrm{R} \leq 3$ & 3.76 & 3.48 & 2.928 & 6.40 \\
\hline 4 & 40 & . & . & . & . & . \\
\hline
\end{tabular}


Since results from the ADF test showed that the time series data became stationary as well as integrated of the same order I(I), the Johansen cointegration test was performed, and subsequently as it is shown in table 4 the variables of the bird-in-hand dividends policy are found to be significantly integrated with investors' preferences, over the long-run. Thus, since results confirmed that banking stability as captured by the ZSI, BM and MC is significantly co-integrated with the dividends' measures; the study moved on to run the ECM to check whether there are long-run causalities running from dividends policies towards banks' stability (see table 5-7).

This table describes the long-run causalities, which are running from dividends' policy towards banks' stability as captured by the Z-score index.

Table 5. Error correction model

\begin{tabular}{lllllll}
\hline & Coef. & Std. Error & $\mathbf{Z}$ & $\mathbf{P}>/ \mathbf{Z} /$ & $\mathbf{9 9 \%}$ Conf. & Interval \\
\hline D_Z-Score Index & & & & & \\
\hline _Ce1 & & & & & \\
\hline L1. & -0.406 & 0.061 & -0.66 & 0.507 & -0.160 & 0.079 \\
\hline _Ce2 & & & & & & \\
\hline L1. & 5065 & 5717 & 0.89 & 0.37 & -6140 & 1627 \\
\hline Z-Score Index & & & & & & \\
\hline LD. & 0.421 & 0.333 & 1.26 & 0.206 & -0.232 & 1.074 \\
\hline EPS & & & & & & \\
\hline LD. & -3568 & 5365 & -0.67 & 0.506 & -1408 & 6947 \\
\hline DPR & & & & & & \\
\hline LD. & 12751 & 11002 & 1.16 & 0.246 & -8813 & 34316 \\
\hline RR & & & & & & \\
\hline LD. & 9778 & 11843 & 0.83 & 0.409 & -13435 & 32991 \\
\hline -Trend & 1.420 & 0.143 & 0.00 & 1.00 & -0.368 & 0.368 \\
\hline _Cons & 0.026 & 2.147 & 0.01 & 0.990 & -5.50 & 5.55 \\
\hline
\end{tabular}

As shown in Table 5, since results from the ECM showed that the error term is negative, while the P-value is not significant; the study confirmed that the stability of banks as proxied by the ZSI is not being granger caused by the quarterly change in EPS, DPR, or the RR during the long-run. Which in other words mean that investors of Amman stock exchange do not rely on the change of dividends' payments when they think to acquire or liquidate their shares at the Jordanian listed banks.

This table describes the long-run causalities, which are running from dividends policies towards banks' stability as captured by Bankometer model.

Table 6. Error correction model

\begin{tabular}{|c|c|c|c|c|c|c|}
\hline & Coef. & Std. Error & $\mathbf{Z}$ & $\mathbf{P}>\mid \mathrm{Z} /$ & 99\% Conf. & Interval \\
\hline \multicolumn{7}{|c|}{ D_Bankometer Model } \\
\hline \multicolumn{7}{|l|}{ _Ce1 } \\
\hline L1. & -0.520 & 0.405 & -1.28 & 0.200 & -1.564 & 0.524 \\
\hline \multicolumn{7}{|c|}{ _Ce2 } \\
\hline L1. & -2561 & 2093 & -1.22 & 0.221 & -7953 & 2830 \\
\hline
\end{tabular}




\begin{tabular}{lllllll}
\hline LD. & -0.655 & 0.234 & -2.79 & 0.005 & -1.260 & -0.049 \\
\hline EPS & & & & & & \\
\hline LD. & 2401 & 2280 & 1.05 & 0.292 & -3472 & 8274 \\
\hline DPR & & & & & & \\
\hline LD. & -3984 & 4930 & -0.81 & 0.419 & -16684 & 8715 \\
\hline RR & & & & & & \\
\hline LD. & -4728 & 4399 & -1.07 & 0.282 & -16059 & 6602 \\
\hline Trend & -7.680 & 0.053 & -0.00 & 1.00 & -0.138 & 0.138 \\
\hline CCons & -0.044 & 0.533 & -0.08 & 0.934 & -1.417 & 1.329 \\
\hline
\end{tabular}

The above Table 6 confirmed that there are no long-run causalities running from the quarterly change in EPS, DPR, or the RR towards banks' stability as gauged by the bankometer model. Which in other words mean that banks' decisions regarding paying dividends do not affect investors' preferences as captured by the stability of Jordanian listed banks, over the long-run.

This table describes the long-run causalities, which are running from dividends policies towards banks' stability as captured by market capitalization.

Table 7. Error correction model

\begin{tabular}{|c|c|c|c|c|c|c|}
\hline & Coef. & Std. Error & $\mathbf{Z}$ & $\mathbf{P}>\mid \mathrm{Z} /$ & 99\% Conf. & Interval \\
\hline \multicolumn{7}{|l|}{ D_MC } \\
\hline \multicolumn{7}{|l|}{ _Ce1 } \\
\hline L1. & -0.0023 & 0.0143 & -0.16 & 0.869 & -0.0392 & 0.0345 \\
\hline \multicolumn{7}{|l|}{ MC } \\
\hline LD. & 0.6653 & 0.3390 & 1.96 & 0.050 & -0.2080 & 1.5386 \\
\hline \multicolumn{7}{|l|}{ EPS } \\
\hline LD. & 11.352 & 195.18 & 0.06 & 0.954 & -491.40 & 514.11 \\
\hline \multicolumn{7}{|l|}{ DPR } \\
\hline LD. & 15.263 & 324.06 & 0.05 & 0.962 & $\begin{array}{l}-819.47 \\
\end{array}$ & 849.99 \\
\hline \multicolumn{7}{|l|}{$\mathbf{R R}$} \\
\hline LD. & -136.38 & 428.60 & -0.32 & 0.750 & -1240.4 & 967.64 \\
\hline _Trend & -0.0018 & 0.0084 & -0.22 & 0.828 & -0.0235 & 0.0198 \\
\hline _Cons & 0.0265 & 0.1275 & 0.21 & 0.835 & -0.3020 & 0.3551 \\
\hline
\end{tabular}

As proved by Table 7 the stability of banks as proxied by market capitalization is not being granger caused by the quarterly change in EPS, DPR, or the RR during the long-run. Which in other words mean that investors of Amman stock exchange do not include dividends policies in the process of decision making. However, since results from ECM asserted that there are no causalities running from dividends policies towards banks' stability, the study proceeds to run the Wald $\chi^{2}$ test to check whether there are short-run correlations between banks' stability along with dividends policies. 
Table 8. Wald $\chi^{2}$ Granger Causality Test

\begin{tabular}{lllllll}
\hline \multirow{2}{*}{ Variables } & ZSI & \multicolumn{3}{l}{ MB } & \multicolumn{2}{l}{ MC } \\
\cline { 2 - 7 } EPS & Chi2 (2) & Prob. > Chi2 & Chi2 (2) & Prob. > Chi2 & Chi2 (2) & Prob. > Chi2 \\
\hline DPR & 3.22 & 0.521 & 5.23 & 0.264 & 1.840 & 0.771 \\
\hline RR & 6.38 & 0.172 & 18.27 & 0.001 & 4.17 & 0.383 \\
\hline
\end{tabular}

As shown in table 8 , results from Wald $\chi^{2}$ test demonstrate that except market capitalization, the stability of banks is not affected by the quarterly change in EPS, DPR or RR during the short-run. Therefore, the study confirmed that the movements in dividends measures such as DPR are significantly motivating or discouraging investors to acquire or liquidate their stocks at the listed banks of Jordan.

This table checks whether or not investors' preferences is valid to mediate the relationship between dividends' stability along with banks' stability as captured by the ZSI.

Table 9. Dividends stability, investors preferences and ZSI pre-estimation tests

\begin{tabular}{|c|c|c|c|c|c|}
\hline \multicolumn{6}{|c|}{ VEC-rank ZSI, trend(trend), Level99, Lags (2) max “Johansen Co-integration Test" } \\
\hline \multicolumn{4}{|c|}{ Trend: Constant } & & $\#$ Obs. $=90$ \\
\hline \multicolumn{4}{|c|}{ Sample: Q3/1996-Q4/2018 } & & Lags $=2$ \\
\hline \multicolumn{6}{|c|}{ Maximum } \\
\hline \multirow[b]{2}{*}{ Rank } & \multirow[b]{2}{*}{ Parms } & \multirow[b]{2}{*}{$\mathrm{H}_{0}$} & ZSI & Investors’ Behaviour & \multirow{2}{*}{$\begin{array}{l}\text { ZSI, Investors' Behaviour, } \\
\text { Dividends' Stability } 1 \% \text { Critical }\end{array}$} \\
\hline & & & Trace Statistic & Trace Statistic & \\
\hline $\mathbf{0}$ & 8 & $\mathrm{R}=0$ & 27.11 & 26.06 & 23.46 \\
\hline 1 & 11 & $\mathrm{R} \leq 1$ & $5.204^{*}$ & $6.309 *$ & 6.40 \\
\hline 2 & 12 & . & . & . & . \\
\hline
\end{tabular}

The present study is also aimed at checking whether investors' preferences act as a mediator to adjust the relationship of dividends' stability along with the ZSI as a proxy for banks' stability. Thus, since results from table 9 showed a long-run integration of the ZSI along with dividends' stability, and similarly a long-run integration was also detected between investors' preferences and dividends stability; the study shifted to regress the ZSI on dividends' stability, as well as investors' preferences on dividends' stability separately (see results in tables 10 "Panel A \& B").

This table shows results from the ECM, which is employed to regress banks' stability on dividends stability and investors preferences on dividends' stability separately. 
Table 10. Banking stability and dividends stability

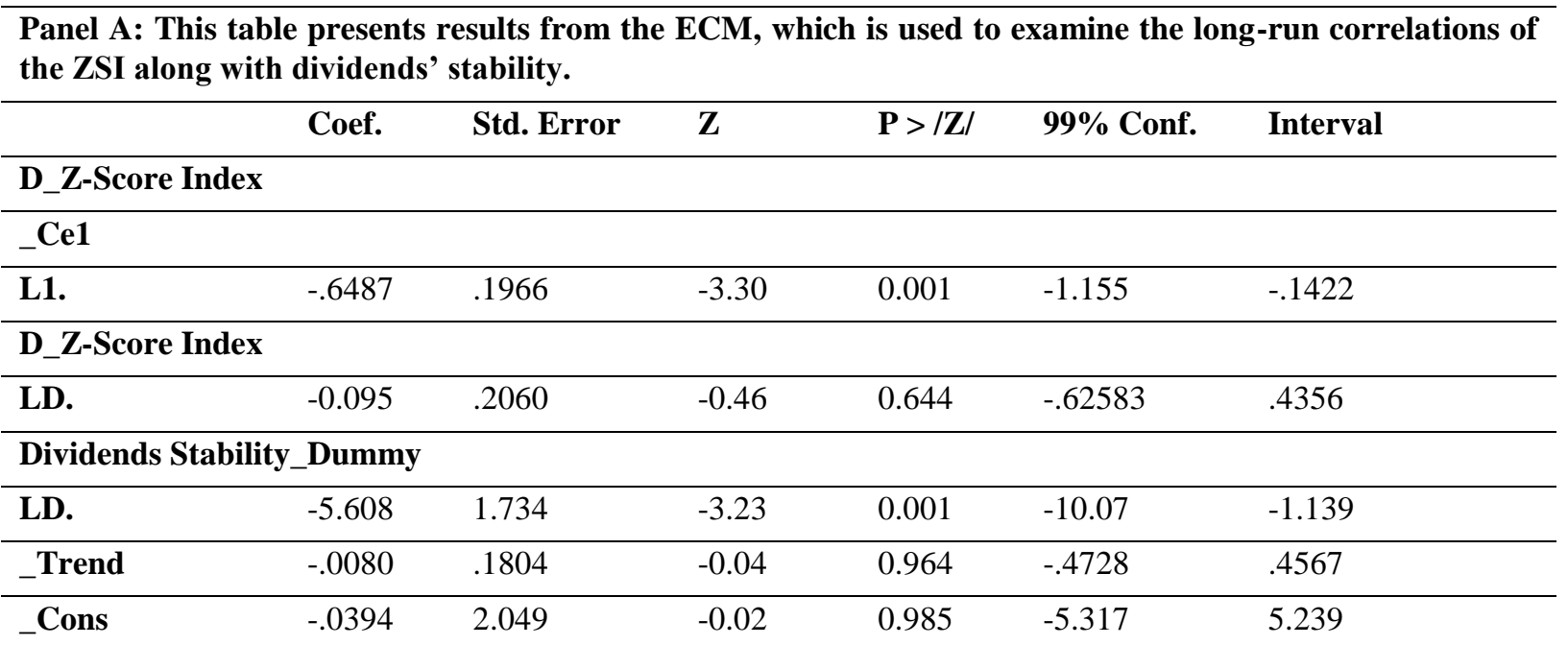

Panel B: This table presents results from the ECM, which is used to regress investors' preferences on dividends' stability, over the long-run.

\begin{tabular}{|c|c|c|c|c|c|c|}
\hline & Coef. & Std. Error & $\mathbf{Z}$ & $\mathbf{P}>/ \mathbf{Z} /$ & 99\% Conf. & Interval \\
\hline \multicolumn{7}{|c|}{ D_Stock Change\% } \\
\hline \multicolumn{7}{|l|}{-Ce1 } \\
\hline L1. & -0.330 & 0.114 & -2.89 & 0.004 & -0.625 & -0.035 \\
\hline \multicolumn{7}{|c|}{ D_Stock Change \% } \\
\hline LD. & -0.490 & 0.169 & -2.89 & 0.004 & -0.927 & -0.052 \\
\hline \multicolumn{7}{|c|}{ Dividends Stability_Dummy } \\
\hline LD. & 0.157 & 0.074 & 2.12 & 0.034 & -0.033 & 0.349 \\
\hline _Trend & -0.008 & 0.010 & -0.80 & 0.422 & -0.036 & 0.018 \\
\hline _Cons & 0.107 & 0.133 & 0.80 & 0.424 & -0.237 & 0.451 \\
\hline
\end{tabular}

As shown in Table 10, after regressing the stability of banks on dividends stability, as well as investors' preferences on dividends stability; results from the ECM showed that the ZSI as well as investors' preferences as captured by the growth of banks' stock prices are separately, and significantly related to dividends' stability during the long-run. Which in other words mean that a $1 \%$ increase in dividends' stability decreases the stability of banks by 5.608 . Therefore, the results indicated that the enhancement of dividends stability at the Jordanian listed banks is negatively impacting banks' stability as captured by the ZSI. By contrast, the results showed that a $1 \%$ increase in dividends stability motivates investors of Jordan to invest into the banks. which in other words, the findings showed that the $1 \%$ enhancement in dividends stability leads to a $15.7 \%$ increase in the stock prices of Jordanian listed banks. Moreover, since the above results confirmed that dividends stability is significantly impacting the stability of banks, as well as investors' preferences; the study can now proceed to test whether investors' preferences are valid to mediate the long-run causalities, which are running from dividends stability towards the stability of banks as proxied by the ZSI.

This table examines the validity of investors' preferences to interrupt the long-run correlation of dividends stability along with banks' stability. 
Table 11. The impact of dividends stability and stock price in banking stability

\begin{tabular}{|c|c|c|c|c|c|}
\hline $\begin{array}{l}\text { Panel } \\
\text { investo }\end{array}$ & $\begin{array}{l}\text { : Results fro } \\
\text { ', preference }\end{array}$ & $\begin{array}{l}\text { ohanse } \\
\text { d divi }\end{array}$ & $\begin{array}{l}\text { nonst } \\
\text { ility. }\end{array}$ & that there are & run integration among \\
\hline VEC-r & ank ZSI, Inves & rs' Pref & Divide & ability, trend(tre & , Level99, Lags (2) max \\
\hline Johans & en Co-integra & n Test & & & \\
\hline Trend & Constant & & & $\#$ Obs. $=90$ & \\
\hline Sampl & Q3/1996-Q4 & & & Lags $=2$ & \\
\hline Maxim & um & & & & \\
\hline Rank & Eigen-value & Parms & $\mathrm{H}_{0}$ & Trace Statistics & $1 \%$ Critical \\
\hline $\mathbf{0}$ & . & 15 & $\mathrm{R}=0$ & 48.55 & 40.49 \\
\hline 1 & 0.742 & 20 & $\mathrm{R} \leq 1$ & 20.10 & 23.46 \\
\hline 2 & 0.515 & 23 & $\mathrm{R} \leq 2$ & 4.899 & 6.40 \\
\hline 3 & 0.208 & 24 & & & \\
\hline
\end{tabular}

Panel B: According to this table, findings from the ECM asserted that banks' stability is not being granger caused neither by dividends' stability nor by investors' preferences. Which in other words mean that when investors' preferences were included in the model as a mediator, no relationship between dividends' stability and the ZSI was detected.

\begin{tabular}{|c|c|c|c|c|c|c|}
\hline & Coef. & Std. Error & $\mathbf{Z}$ & $P>|Z|$ & 99\% Conf. & Interval \\
\hline \multicolumn{7}{|c|}{ D_Z-Score Index } \\
\hline \multicolumn{7}{|l|}{ _Ce1 } \\
\hline L1. & -0.425 & 0.1817 & -2.34 & 0.019 & -0.893 & 0.0428 \\
\hline \multicolumn{7}{|c|}{ D_Z-Score Index } \\
\hline LD. & 0.046 & 0.219 & 0.21 & 0.833 & -0.519 & 0.612 \\
\hline \multicolumn{7}{|c|}{ Dividends Stability_Dummy } \\
\hline LD. & -4.493 & 2.265 & -1.98 & 0.047 & -10.32 & 1.343 \\
\hline \multicolumn{7}{|c|}{ Stock Change \% } \\
\hline LD. & -8.547 & 2.400 & -3.56 & 0.000 & -14.73 & -2.363 \\
\hline _Trend & -0.002 & 0.172 & -0.010 & 0.988 & -0.447 & 0.441 \\
\hline _Cons & 0.895 & 2.219 & 0.400 & 0.687 & -4.822 & 6.613 \\
\hline
\end{tabular}

Since the above Table 10 proved that investors' preferences is valid to be utilized as a mediator, the Johansen test was applied to find out whether investors' preferences are able to adjust the long-run integration of dividends' stability along with banking stability. However, although results from Table 11-panel A, proved that there are long-run integration among dividends' stability, investors' preferences and the ZSI; results from the ECM as demonstrated by panel B confirmed that the stability of banks is not being granger caused neither by dividends stability nor by investors' preferences. Which in other words mean that when investors' preferences were included in the model as a mediator, no relationship between dividends' stability and the ZSI was detected. Based on these results the study indicated the stability of Jordanian banks is not impacted by the nature of relationship between dividends' stability and investors' preferences. However, to check whether investors' preferences are valid to adjust the short-run correlation of dividends' stability along with the ZSI; the granger causality Wald $\chi^{2}$ was finally applied. This table examines the validity of investors' preferences to interrupt the short-run relationship of banks' stability along with dividends' stability, over the short-run. 
Table 12. Granger causality wald $\chi^{2}$ test

\begin{tabular}{lll}
\hline Variables & Chi2 (2) & Prob. $>$ Chi2 \\
\hline Dividends Stability & 18.39 & 0.005 \\
\hline Stock change\% & 79.05 & 0.000 \\
\hline
\end{tabular}

Although results from the ECM as shown in Table 11 confirmed that the stability of banks is not being granger caused by dividends stability or investors preferences, however, the above Table 12 proved that the stability of banks as proxied by the ZSI is significantly related to dividends' stability and investors' preferences in the short-run. Therefore, the study found that since dividends' stability has a power to impact the growth of stock prices it can be concluded that the change in stock prices play a vital role to affect investors' decisions, and subsequently that will affect the stability of Jordanian listed banks as captured by the ZSI. Accordingly, investors' preferences are found to be valid to mediate the relationship of dividends' stability along with the ZSI, during the short-run.

\section{Conclusion and Recommendations}

This paper concerns of assessing the effectiveness of the bird-in-hand dividends policy as represented by the EPS, DPR and RR in the stability of Jordanian listed banks as a main proxy for investors' preferences. According to this research, banks' stability was mainly gauged by utilizing variables such as the Z-score index, market capitalization and the bankometer model as a measure for banks' solvency. To achieve the core aim of this research the study employed a set of advanced empirical techniques to analyze a time series data covering the period Q1/1996-Q4/2018. Thus, since time series data are vulnerable to increase or decrease over time, the study applied the augmented dickey fuller test to check for data's stationarity as well as avoiding the problem of getting spurious regression findings. Consequently, the results confirmed that the used series variables became stationary only after including the first difference. However, since results from Johansen test revealed that the trace values are higher than their critical values; the study ran the ECM to investigate the long-run causalities, which are running from dividends policy towards banks' stability. As a result, the study failed to accept the first sub-hypothesis, which is in other words mean that the stability of banks is not related to the quarterly change in EPS, DPR, or RR over the long-run. This result disagrees with Luvembe, et al. (2014); Agyei (2011) as they confirmed that the value of banks is positively relating to dividends payout ratio. Consistently, Amidu (2007) revealed that banks' return on assets is positively related to dividends policy. Alternatively, studies including Lilian (2016) showed that banks' performance as proxied by ROA is insignificantly related to dividends per share. Based on the achieved results, the study concluded that investors of ASE don't rely on the assumptions of the relevance dividends theory, when they think to invest into the banks. In other words, investors of ASE are not following the bird-in-hand dividends policy, which states that investors prefer dividends over capital gains, which are to some extent seen to be uncertain (Lintner, 1962; Gordon, 1963).

However, though results from the ECM showed that dividends' stability is significantly impacting the stability of banks during the long-run, however, after including investors' preferences in the model this effect was totally eliminated. Thereby, the study concluded that during the long-run the correlation of dividends along with banks' stability is mostly relied on variables other than investors' preferences. Additionally, the study showed that a $1 \%$ increase in dividends' stability increases the stock prices of banks by $15.7 \%$. Authors including Azam and Kumar (2011) proved that E/P is significantly affecting the stock index of Karachi stock market as proxied by investors' behaviour. However, Ali (2020) showed that the behaviour of Amman stock exchange's investors as captured by the stock index is not related to the change in P/E, EPS and DYR in the long-run. However, since the current research revealed that investors' preferences is significantly related to dividends' stability; the study concluded that investors of Jordan prefer to invest in the stocks, which are paying stable dividends, instead of investing in stocks which are assumed to decrease or retain dividends.

By contrast, results from the Wald $\chi^{2}$ test confirmed that banks' stability as measured by the BM is significantly related to the change in DPR during the short-run. In this regard, the study induced that banking stability is significantly affected by the change in banks' decisions regarding dividends' distributions. Furthermore, since results from Wald $\chi^{2}$ test revealed that the stability of banks relies on investors' preferences during the short-run, the study derived that when banks relies on EPS to adjust their DPR that is expected to be significantly linked with banking stability, due to the impact of dividends' stability in the way of how investors thinking towards investing in banks' stocks. Studies including Ali (2020) revealed that the perceptions of ASE's investors are significantly impacted by dividends policies during the short-run. On the contrary, the study asserted that the stability of banks as captured by $\mathrm{MC}$ is not being granger caused by dividends policy during the short-run. However, based on the aforementioned 
findings the study concluded that during the short-term investors of ASE are found to be proponents for the bird-in-hand dividends policy, while during the long-term they are found not to follow the assumptions of the relevance dividends theory. Therefore, the study recommends that it is necessary for Jordanian listed banks to rely on dividends decisions in order to anticipate investors' preferences during the short-run. Additionally, it is important for banks to be cautious of cutting dividends, because that will affect their performance, since investors of Jordan prefer to invest into the stocks, which are paying stable dividends. Furthermore, there is a necessity for further researchers to search for the other influential factors of banking stability, as well as measuring the relationship of the irrelevance dividends policy along with banks' stability and investors' reactions.

\section{Acknowledgment}

This research is financed by the Deanship of Scientific Research in Zarqa University.

\section{References}

Abdul Karim, N., Alhabshi, S., \& Abduh, M. (2016). Macroeconomic indicators and bank stability: A case of banking in Indonesia. Buletin Ekonomi Moneter dan Perbankan, 18(4), 432-448. https://doi.org/10.21098/bemp.v18i4.609

Agyei, S. (2011). Dividend Policy and Bank Performance in Ghana. International Journal of Economics and Finance, 3(4), 202-207.

Ali, M. S. (2016). The impact of market fundamentals and financial crisis on the liquidity of banks and Stock Markets: Evidence from Jordanian investors. Unpublished doctoral dissertation, Anglia Ruskin University.

Ali, M. S. (2020). An empirical analysis for the perceptions of Amman stock exchange's investors. Business: Theory and Practice, 21(1), 125-135. http://doi.org/10.3846/btp.2020.11206

Almeida, P., \& Tavares. (2015). Determinants of Dividend Policy: Evidence from Portugal. Revista Brasileira de Gestao e Negocios. Review of Business Management. https://doi.org/10.4270/ruc.2014435

Amidu, M. (2007). How does dividend policy affect performance of the firm on Ghana stock exchange?. Investment Management and Financial Innovations, 4(2), 103-111.

Amman Stock Exchange. (2019). Retrieved from https://www.ase.com.jo/

Audo, P. N. (2014). The relationship between inflation rates and liquidity of commercial banks in Kenya.

Azam, M., \& Kumar, D. (2011). Factors Influencing the Individual Investor and Stock Price Variation: Evidence from Karachi Stock Exchange. Australian Journal of Basic and Applied Sciences, 5(12), 3040-3043.

Bressan, S. (2017). The interplay between dividends and leverage inside commercial banks. International Journal of Financial Research, 8(2), 7-36. https://doi.org/10.5430/ijfr.v8n2p7

Central Bank of Jordan. (2019). Retrieved from http://www.cbj.gov.jo/

Diaconu, L., \& Oanea, D. (2015). Determinants of bank's stability. Evidence from Credit Coop. Procedia Economics and Finance, 32, 488-495. https://doi.org/10.1016/S2212-5671(15)01422-7

Fadare, S. O. (2011). Banking sector liquidity and financial crisis in Nigeria. International Journal of Economics and Finance, 3(5), 3-11. https://doi.org/10.5539/ijef.v3n5p3

Gordon, M. J. (1963). Optimal Investment and Financing Policy. Journal o Finance, 18(2), 264-272. https://doi.org/10.1111/j.1540-6261.1963.tb00722.x

Gordon, M. J., \& Shapiro, E. (1956). Capital Equipment Analysis: The Required Rate of Profit. Management Science, 3(1), 102-110. https://doi.org/10.1287/mnsc.3.1.102

Haron, S., \& Azmi, W. N. (2006). Deposit determinants of commercial banks in Malaysia. Finance India, 10(2), $2-21$.

Imran, K., Usman, M., \& Nishat, M. (2013). Banks dividend policy: Evidence from Pakistan. Economic Modeling, 32(2013), 88-90. https://doi.org/10.1016/j.econmod.2013.01.041

Irungu, P. (2013). The effect of interest rate spread on financial performance of commercial banks in Kenya. Unpublished master thesis, University of Nairobi.

Jepkemoi, A., Odoyo, F., Simiyus, R., \& Onyango, R. (2019). The Influence of financial performance on dividend payout ratio of commercial banks Listed at the Nairobi securities exchange, Kenya. The Strategic Journal of Business \& Change Management, 6(3), 371-387. 
Lilian, N. (2016). Effects of Dividend Policy on Financial Performance of Listed Banks in Kenya. Unpublished Master Thesis, University of Nairobi.

Lintner, J. (1956). Distribution of incomes of corporations among dividends, retained earnings, and taxes. The American Economic Review, 46(2), 97-113.

Lintner, J. (1962). Dividends, earnings, leverage, stock prices and supply of capital to corporations. The Review of Economics and Statistics, 64, 243-269. https://doi.org/10.2307/1926397

Lundgren, B. (2016). Ownership structure's effect on dividend policy: Evidence from publicly listed Swedish firms. Unpublished Master Thesis, Umea University.

Luvembe, L., Njangiru, M., \& Mungami, E. (2014). Effect of dividend payout on market value of listed banks in Kenya. International Journal of Innovative Research and Development, 3(11), 1-21.

Malik, M. F., \& Rafique, A. (2013). Commercial banks liquidity in Pakistan: Firm specific and macroeconomic factors. The Romanian Economic Journal, 48, 139-54.

Miller, M., \& Modigliani, F. (1961). Dividend policy, growth, and the valuation of shares. The Journal of Business, 34(4), 411-433. https://doi.org/10.1086/294442

Mojgan, S., \& Ali, M. (2011). Examining the effect of earnings per share and cash dividends per share on investor decision making in Tehran stock exchange from the capital market participants' view. American Journal of Scientific Research, 36, 99-106.

Oktaviyanti, D., \& Purnawan, M. (2019). The behaviour of banking stability in ASEAN-5. Economic Papers, 18(4), 329-344. https://doi.org/10.1111/1759-3441.12267

Riaz, S., \& Mehar, A. (2013). The impact of bank specific and macroeconomic indicators on the profitability of commercial banks. The Romanian Economic Journal, 47, 91-110.

Subedi, S., \& Neupane, B. (2013). Determinants of banks' liquidity and their impact on financial performance in Nepalese commercial banks. Unpublished master thesis, Pokhara University.

The Global Economy. (2019). Retrieved October 08, 2019, from https://www.theglobaleconomy.com/

Wahid, M., \& Dar, H. (2016). Stability of Islamic versus conventional banks: A Malaysian case. Journal Ekonomi Malaysia, 50(1), 111-132. https://doi.org/10.17576/JEM-2016-5001-09

Yamin, I., \& Ali, M., S. (2016). Evaluating the financial soundness of the Jordanian commercial banks by applying bankoMeter's model. Research Journal of Finance and Accounting, 7(2), 124-130. 